\title{
PENTINGKAH LOGBOOK UNTUK PENILAIAN KINERJA KELOMPOK?
}

\author{
Dasrieny Pratiwi ${ }^{1}$ \\ Kartika Sari ${ }^{2}$ \\ ${ }^{1,2}$ Pendidikan Biologi FKIP Universitas Muhammadiyah Metro \\ E-mail:dasrienyp@yahoo.com,kartika.ummetro@gmail.com
}

\begin{abstract}
This present study aimed to implement logbook on Media Pembelajaran subject to assess the group performance. Questionnaire were used to collect the data. Qualitative analysis showed that using logbook is effective for assess the performance of group. The result also showed the students who contribute to the group and how they work. We can conclude that assessing of group performance by using logbook is effective and recommended for other subject to use it. Combining the logbook instrument and learning instructional would be suggested.
\end{abstract}

Kata Kunci: logbook, learning instrument, group performance assessment

Perkuliahan media pembelajaran merupakan mata kuliah wajib yang diikuti mahasiswa calon guru biologi. Pada mata kuliah ini mahasiswa dibekali bagaimana memilih, menentukan, menggunakan, dan mengembangkan media pembelajaran biologi. Tugas yang diberikan pada matakuliah ini yaitu mahasiswa diminta untuk mengembangkan media pembelajaran, baik secara individu maupun tugas kelompok.

Strategi pembelajaran yang digunakan dosen pengampu pada matakuliah ini dengan menggunakan model pemeblajaran Project Based Learning (PjBL). Model ini dipilih karena dinilai tepat untuk karakter perkuliahan media pembelajaran. Project yang dimaksudkan dalam perkuliahan yaitu project untuk mengembangkan media pembelajaran untuk materi-materi biologi, baik ditingkat SMP maupun SMA.

Project yang dikerjakan mahasiswa terbagi menjadi dua macam. Yang pertama Bersifat individu dan yang kedua dikerjakan secara berkelompok. Untuk Project yang dikerjakan secara individu nyaris selama ini tidak ada kendala yang dihadapi. Namun, untuk project yang dikerjakan secara berkelompok setiap tahunnya dosen pengampu selalu mendapatkan keluahan dari mahasiswa.

Keluahan-keluhan

itu disampaikan kepada dosen pengampu setelah mereka selesai mengerjakan. Mulai dari meminta untuk waktu berkonsultasi mengenai media yang akan dikembangkan, kesesuain materi yang dipilih dengan media yang dikembangkan, serta kinerja dari anggota kelompok yang tertumpu pada beberapa anggota saja.

Menyadari pentingnya
program pembelajaran, yang
merupakan pangkal dari pembekalan
pembekalan peserta didik untuk
memiliki kompetensi (Suarta, 2012).
Maka dosen pengampu mengadakan
perbaikan-perbaikan dari sisi
manapun demi pencapaian tujuan
perkuliahan.


Untuk itu, berdasarkan keluhan yang telah disampaikan mahasiswa tadi maka, selaku dosen pengampu kami di tahun berikutnya memberikan kesempatan untuk mahasiswa yang mengerjakan project kelompok untuk mengkonsultasikan terkait permasalahan dalam pengemabnagan media yang dikembangkan. Dengan berjalanannya perkuliahan, keluhan pertama pun sudah terminimalisir dengan solusi yang dipilh dosen, namun, untuk keluhan kedua. Yaitu, kinerja kelompok yang hanya tertumpu pada anggota tertentu saja, selalu dikeluhkan oleh setiap kelompok.

Hal ini mejadi permasalahan tersendiri, karena bagi anggota kelompok yang bekerja sungguhsungguh mereka merasa ketidak adilan dalam penilaian, karena mereka yang bekerja mendapatkan nilai yang sama dengan mereka yang tidak bekerja, karena nama mereka tercantum sebagai anggota dari kelompok. Sehingga, project yang dibuat kelompok, kemudian dinilai oleh dosen. Dan nilai tersebut diperuntukkan untuk nilai kelompok, yang artinya, semua anggota kelompok mendapatkan nialai yang sama. Padahal, yang bekerja hanyalah beberapa orang saja.

Untuk itu selaku dosen pengampu, kami pun mencarikan solusi dalam permasalah tersebut yaitu dengan meminta kepada kelompok untuk melampirkan logbook dari apa yang telah mereka kerjakan dengan menampilkan gambar disetiap kinerja yang mereka lakukan sebagai dasar penilaian. Hal ini sesuai dengan yang disampaikan dari hasil penelitian Rosana(2009), yang menyatakan bahwa penilaian merupakan salah satu komponen yang tidak kalah penting dalam pembenahan untuk mendapatkan pendidikan yang lebih baik.

\section{METODE}

Metode yang digunakan dalam penelitian ini yaitu metode penelitian yang deskriptif. Dimana alat yang digunakan untuk mengumpulkan data dengan menggunakan anggket dan dilengkapi dengan wawancara. Angket digunakan untuk menjaring persepsi mahasiswa dengan diberlakukannya penggunaan logbook pada matakuliah media pembelajaran. Selain angket, wawancara pun dilakukan untuk mendapatkan informasi langsung terkait penggunaan logbook yang tidak tercakup di dalam angket.

\section{HASIL}

Sebanyak 54 orang responden yang diminta mengisi angket. Angkat yang dibagikan terkait dengan penggunaan logbook dalam penilaian kinerja kelompok, maka diperoleh data seperti yang di sajikan pada tabel di bawah ini: 
Tabel 1. Persentase Angket tentang Logbook

\begin{tabular}{|l|l|r|r|r|r|}
\hline \multirow{2}{*}{ No } & \multicolumn{1}{|c|}{ Pernyataan } & \multicolumn{3}{|c|}{ Persentase pilihan (\%) } \\
\cline { 3 - 6 } 1 & SS & \multicolumn{1}{|c|}{ S } & \multicolumn{1}{|c|}{ TS } & \multicolumn{1}{|c|}{ STS } \\
\hline 2 & $\begin{array}{l}\text { Melampirkan logbook kinerja harian untuk } \\
\text { individu }\end{array}$ & 9,26 & 53,70 & 31,48 & 5,56 \\
\hline kelampirkan lembar logbook untuk kerja & 42,59 & 55,56 & 0 & 1,85 \\
\hline 3 & $\begin{array}{l}\text { Menggunakan logbook sangat efektif } \\
\text { melaporkan kepada dosen siapa saja } \\
\text { anggota kelompok yang tidak bekerja }\end{array}$ & 50,00 & 46,30 & 1,85 & 1,85 \\
\hline 4 & $\begin{array}{l}\text { Segan menegur rekan yang tidak bekerja } \\
\text { di dalam kelompok }\end{array}$ & 11,11 & 51,85 & 29,63 & 7,41 \\
\hline 5 & $\begin{array}{l}\text { Penentuan tugas untuk masing- masing } \\
\text { anggota kelompok menghindari dominasi } \\
\text { di antara anggota kelompok lainnya }\end{array}$ & 37,04 & 61,11 & 1,85 & 0 \\
\hline 6 & Menggunakan logbook sangat merepotkan & 5,56 & 12,96 & 64,81 & 16,67 \\
\hline 7 & $\begin{array}{l}\text { Menggunakan logbook untuk matakuliah } \\
\text { lain }\end{array}$ & 9,26 & 57,41 & 27,78 & 5,56 \\
\hline
\end{tabular}

Keterangan:
SS = Sangat Setuju
$\mathrm{S} \quad=$ Setuju
TS $\quad=$ Tidak Setuju
STS $=$ Sangat Tidak Setuju

Adapun untuk melihat keterkaitan antar persentase pilihan dari tiap pernyatan disajikan pada gambar berikut:

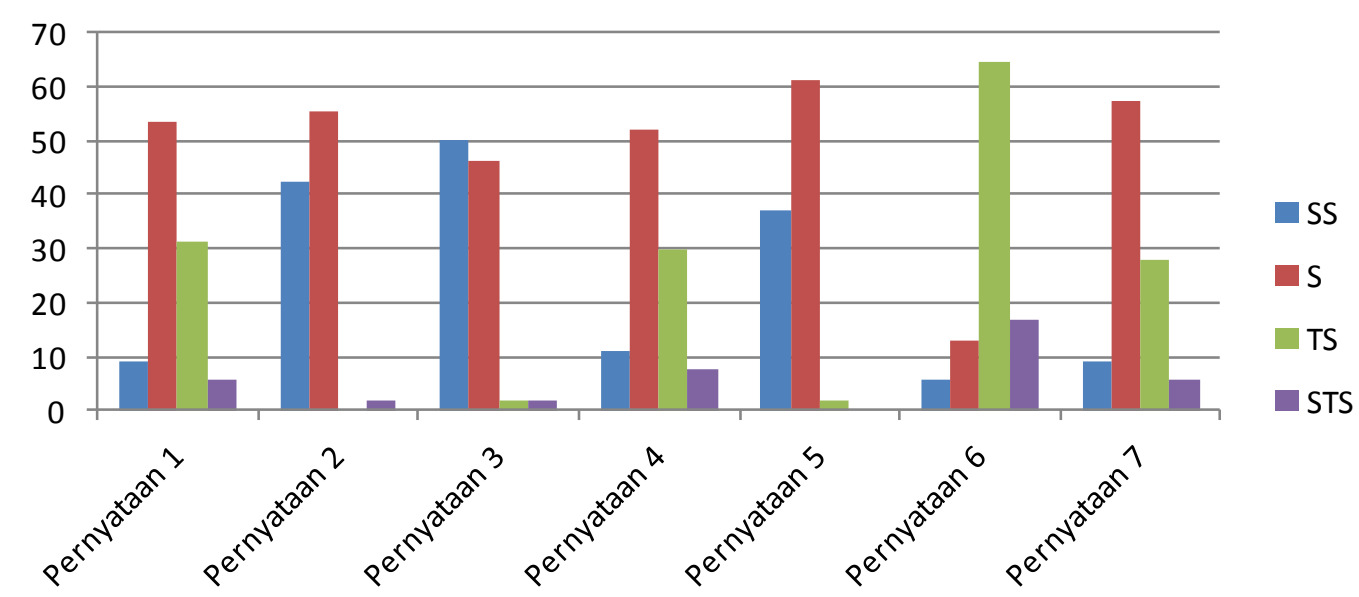

Gambar 1. Persentase Pilihan Tiap Penyataan

\section{PEMBAHASAN}

Berdasarkan data yang disajikan, untuk pernyataan pertama, dari 54 orang responden sebanyak $53,70 \%$ menyatakan setuju untuk melampirkan logbook di tugas individu. Sedangkan 31, $48 \%$ menyatakan tidak setuju karena dianggap tidak perlu untuk melampirkan logbook sebagai bukti kinerja untuk tugas individu.

Pada pernyataan ke 2, sebanyak $55,56 \%$ menyatakan setuju untuk melampirkan logbook dalam tugas kelompok. 42,59\% menyatakan sangat setuju untuk melampirkan, sisanya sebanyak 
$1,85 \%$ sangat tidak setuju melampirkan logbook pada tugas kelompok, karena dianggap merepotkan. Dengan melampirkan logbook keterlibatan dari tiap individu dapat diketahui.

Keterlibatan dalam kerja di kelompok inilah yang dikenal dengan partisipasi. Menurut Mustajab, M., Sriyono, dan Fatmaryanti (2012), Partisipasi adalah keterlibatan seseorang baik pikiran maupun tenaga untuk memperoleh manfaat dari kegiatan tersebut. hasil belajar dipengaruhi oleh partisipasi siswa, sehingga tidak hanya aspek kognitif saja yang diperoleh namun juga aspek sosial yang berkembang melalui pembelajaran kooperatif script. Partisipasi peserta didik dapat diamati melalui pedoman observasi dalam diskusi kelompok, yang salah satu indikatornya adalah tanggung jawab kelompok.

Jika dengan berdiskusi kelompok yang dilakukan di kelas guru dapat mengobservasinya. Maka, bagaimana dengan diskusi yang dilakukan diluar kelas, tentunya hal ini dapat mempersulit dulu dalam penilaiannya. Dengan demikian dibutuhkannya suatu instrumen yang dapat mengetahui partisipasi dari individu, untuk kelompoknya dengan mendokumentasikan kerja kelompoknya dalam bentuk logbook. Menurut Fatimah (2012) dalam penelitiannya menyarankan agar dalam penilian kinerja kelompok untuk bisa mengembangkan rubrik penilaiannya, sehingga kinerja individu dalam kelompok dapat diukur juga

Pernyataan berikutnya, diperoleh sebanyak $50 \%$ sangat setuju untuk menggunakan logbook sebagai cara yang efektif dalam melaporkan kepada dosen siapa saja anggota kelompok yang tidak bekerja. Sebanyak 46,30\% menyatakan setuju dan masingmasing $1,85 \%$ untuk pilihan tidak setuju dan sangat tidak setuju.

Melalui logbook, sebanyak $50 \%$ menyatakan sangat setuju bahwa mereka bisa melaporkan secara nyata jika ada anggota kelompok yang tidak berpartisipasi di dalam kerja kelompok, tanpa harus menyampaikan secara lisan serta dapat dibuktikan dengan logbook tersebut. Hasil wawancara langsung, diperoleh informasi bahwa mereka merasa keberatan jika ada anggota yang tidak bekerja namun memperoleh nilai yang sama, padahal anggota tersebut tidak bekerja, sedangkan anggota kelompok lainnya yang bekerja merasa ketidak adilan, dan dengan menggunakan logbook mereka dapat melaporkan ke dosen yang bersangkutan serta melampirkan bukti dari apa yang di keluhkan yaitu, adanya anggota yang tidak berpartisipasi.

Dengan demikian penggunaan logbook ini dapat menjadikan sarana dalam menciptakan rasa adil. Dan rasa adil inilah yang nantinya akan menghambat adanya kecemburuan diantara peserta didik. Sehingga, jika dalam pembelajaran guru menanam kan hal ini, khususnya dalam penilaian yang adil maka dapat menjadikan suatu solusi dalam memperbaiki dunia pendidikan. Karena Penilaian merupakan salah komponen yang tidak kalah penting dalam pembenahan untuk mendapatkan pendidikan yang lebih baik (Rosana, 2009)

Selanjutnya, berdasarkan hasil angket yang dibagikan untuk pernyataan keempat berkaitan dengan segan untuk menegur rekan yang tidak bekerja di kelompok, sebanyak 51,85\% menyatakan setuju, 
dan $29,63 \%$ menyatakan tidak setuju, sisanya berturut-turut $11,11 \%$ sangat setuju, dan 7,41 sangat tidak setuju. Berdasarkan data yang diperoleh rasa segan untuk menegur rekan yang tidak bekerja dalam kelompok disetujui sebanyak 51,85\%, hal ini, mengindikasikan bahwa rasa segan menegur dan menyampaikan ke dosen yang bersangkutan mengenai rekan yang tidak bekerja dalam kelompok dapat menimbulkan keresahan dikalangan peserta didik lainnya. Adanya penentuan kerja bagi tiap anggota kelompok dinyatakan dapat menghindari dominasi dalam kelompok sebanyak $61,11 \%$ menyatakan setuju, 37,04 Sangat setuju, dan 1,85\% tidak setuju.

Sedangkan bagi individu yang tidak bekerja itu, memberikan dampak yang negatif baginya untuk kedepannnya. Karena mereka yang tidak dan mengamali kesulitan dalam bekerja bersama kelompok akan sulit menerima dan menyesuaikan diri dengan orang lain. Dan jika hal ini dibiarkan, maka berdampak buruk bagi individu tersebut, yang akan menghadapi dunia kerja dimasa yang akan datang.

Menurut Cairney (2000), Kedepannya dalam era yang penuh persaingan, dunia kerja membutuhkan mereka yang mampu bekerja secara independen, mampu mengelola diri sendiri, bekerjasama dalam tim, beradaptasi dengan perubahan, memecahkan masalahmasalah yang kompleks, serta berpikir secara kreatif dan inovatif. Jika kompetensi-kompetensil ini tidak dibekalkan dalam pembelajaran, maka mereka akan mengalami kesulitan dimasa yang akan datang. Karena sesungguhnyaa program pembelajaran merupakan pangkal dari pembekalan pembekalan peserta didik untuk memiliki kompetensi (Suarta,2012).

Dalam hal penggunaan logbook yang dianggap merepotkan, sebanyak $64,81 \%$ menyatakan tidak setuju. Dan $12,96 \%$ setuju, sedangkan sisanya 5,56 sangat setuju, dan 16,67 sangat tidak setuju. Meskipun dianggap tidak merepotkan bagi kelompok dalam melampirkan logbook. Namun dalam pelaksanaanya diperkuliahan suatu persiapan yang harus dialkukan oleh dosen. Dimana persiapan yang dimaksud terkait dengan program pebelajaran dan penilaian serta tugas yang diberikan kepada mahasiswa (peserta didik), dalam hal ini ketika dosen hendak mengajar maka persiapan untuk membuat logbook pun dilakukan. Hal ini bertujuan untuk menghindari kendala-kendala dalam proses pembelajaran yang akan berlangsung. Karena Salah satu diantara hambatan dalam pemenuhan Standar Naional Pendidikan yaitu, pada bagian Proses, yang mana hambatan nya berupa belum terpenuhinya target yang ada di RPP sehingga pembelajaran di kelas terkadang terganggu karena hal-hal teknis sehingga upaya yang sebaiknya dilakukan yaitu melakukan persiapan teknis agar tidak terganggu proses pembelajaran (Raharjo, 2012).

Jika diminta untuk menggunakan logbook pada matakuliah lain selain dari media pembelajatan maka sebanyak $57,41 \%$ menyatakan setuju untuk menggunakannya dan $27,78 \%$ tidak setuju untuk menggunakannya dalam mata kuliah lain, sedangkan sisanya sebanyak $9,26 \%$ sangat setuju dan $5,56 \%$ sangat tidak setuju. Untuk menggunakan logbook pada matakuliah lain yang didalamnya memberikan tugas kelompok, maka 
logbook dapat digunakan sebagai instrumen pengukuran dalam evaluasi. Namun demikian harus disesuaikan pula dengan prinsip evaluai seperti yang disampaikan oleh Dimyati dan Mujiono (2006), menyatakan bahwa terd apat beberapa faktor yang mempengaruhi kepraktisan instrumen evaluasi meliputi:

a. Kemudahan administrasi

b. Waktu yang disediakan untuk melancarkan kegiatan evaluasi

c. Kemudahan menskor

d. Kemudahan interpretasi dan aplikasi

e. Tersedianya bentuk instrumen evaluasi yang ekuivalen atau sebanding

Dengan demikian, jika logbook dapat memenuhi prinsip-prinsip tersebut maka dapat digunakan secara general. Untuk itu perlu adanya penelitian lanjutan untuk memperbaiki logbook dalam penilaian kinerja kelompok. Namun demikian, melalui logbook dapat diketahui rasa tanggung jawab dari tiap anggota terhadap kualitas kerja dari kelompoknya, dilihat dari banyaknya partisipasi anggota kelompok selama kegiatan yang dilakukan kelompok, yang dibuktikan dengan dokumentasi pada logbook. Karena tanggung jawab, merupakan ciri dari kemandirian dari seorang peserta didik serta dapat bekerjasama merupakan ciri dari menyesuaikan diri (Febriana dan Sabiran, 2001)

Selain menggunakan logbook, untuk mengembangkan rasa tanggung jawab dapat ditingkatkan melalui kegiatan pembelajaran yang diikuti peserta didik. Seperti yang disampaikan oleh Hertiavi dan Langlang (2010), menyatakan bahwa rasa tanggung jawab dapat ditingkatkan melalui pembelajaran kooperatif learning. Dengan demikian memadukan pembelajaran kooperatif learning dan penggunaan logbook untuk mengukur kinerja kelompok, maka dapat menjadikan suatu alternatif kegiatan pembelajaran yang mengembangkan kompetensi serta meningkatkan rasa tanggung jawab dan tak lupa menghindari rasa ketidak adilian diantara anggota kelompok. Untuk ini, perlu adanya penelitian lanjutan dalam rangka mewujudkan hal tersebut, demi tercapainya pemenuhan standar nasional pendidikan.

\section{KESIMPULAN}

Berdasarkan data dan pembahasan, maka kesimpulan yang digunakan dalam penelitian ini yaitu:

1. Dari 54 responden, $55,56 \%$ menyatakan setuju, $42,59 \%$ sangat setuju untuk menggunakan logbook dalam penilaian kinerja kelompok

2. Selain pada matakuliah media pembelajaran, penggunaan logbook juga dapat diberlakukan pada matakuliah lain.

3. Penggunaan logbook membantu perolehan nilai yang lebih objective. Sehingga dapat dijadikan alat untuk penilaian bagi guru maupun dosen dalam menilai kinerja kelompok

4. Perlu adanya pengembangan dari logbook yang digunakan pada penelitian ini, baik secara essensi penilaian maupun secara format tampilan logbook. 
SARAN

1. Logbook dapat digunakan pada matakuliah lain untuk menilai kinerja kelompok

2. Pengembangan logbook untuk penilaian kinerja perlu dikembangkan melalui pembuatan rubrik dalam penilaian logbook

3. Perlunya penelitian lanjutan untuk mengembangkan penilaian kinerja kelompok melalui logbook

4. Pengintegrasian penilaian logbook dalam pembelajaran berlu di uji kaitannya dengan pemahaman peserta didik terhadap konsep yang diperoleh.

\section{DAFTAR RUJUKAN}

Cairney, T. 2000. The knowledge based economy: Implications for vocational education and training. Centre for Regional Research \& Innovation (CRRI) University of Western Sydney. Diakses pada tanggal 12 Juli 2014 dari http://tre vorcairney.com/file/u ploads/cgilib.22733.1.VETLit Rview.pdf

Dimyati dan Mujiono. 2006. Belajar dan Pembelajaran. Jakarta: Rhineka Cipta

Fatimah, Fatia. 2012. 'Kemampuan Komunikasi Matematis dan Pemecahan Masalah melalui Problem Based Learning". Jurnal Penelitin dan Evaluasi Pendidikan. Tahun 16. No.1. hal; 249-259

Febriana, Rina dan Sarbiran. 2001. 'Pengaruh Kemandirian dan Kemampuan menyesuaikan diri terhadap prestasi Belajar Siswa Full DAY School". Jurnal Penelitian dan
Evaluasi. No.4 Tahun III. Hal: 54-61

Hertiavi, M.A., Langlang, H. 2010.

Penerapan

Model

Pembelajaran Kooperatif Tipe

Jigsaw untuk Peningkatan

Kemampuan Pemecahan

Masalah Siswa SMP. Jurnal

Pendidikan Fisika Indonesia.

Vol.6 Januari.; Hal 53-57.

Mustajab, M., Sriyono, dan

Fatmaryanti. 2012.

'Penerapan Model

Pembelajaran Cooperative

Script Untuk Meningkatkan

Partisipasi Belajar Siswa

Kelas VIII A SMP Negeri 2

Karanggayam Tahun

Pelajaran 2012/2013”.

Radiasi Vol1. No1. Hal: 3640

Raharjo, Sabar Budi. 2012.

"Evaluasi Trend Kualitas

Pendidikan di Indonesia".

Jurnal Penelitian dan

Evaluasi Pendidikan. Tahun

16, Nomor 2. Hal : 511-532

Rosana, Dadan. 2009. "Model

Pembelajaran Lima Domain

Sains dengan Pendekatan

Kontekstual untuk

Mengembangkan

Pembelajaran Bermakna”.

Jurnal Penelitian dan

Evaluasi Pendidikan. Tahun

13. No.2 Hal: $268-285$

Suarta, I Made. 2012."Hubungan Sistem Pembelajaran , Lingkungan Belajar, Konsep diri, dan Pengembangan Employability Skill Mahasiswa". Jurnal Penelitian dan Evaluasi Pendidikan. Edisi Dies Natalis Ke-48 UNY. Hal: 2441 